\title{
Research
}

\section{Engaging Local Communities in Low Emissions Land-Use Planning: a Case Study from Laos}

\author{
Jeremy Bourgoin $^{1,2,3}$, Jean-Christophe Castella $^{2,3}$, Cornelia Hett $^{4,5}$, Guillaume Lestrelin $^{2,3}$ and Andreas Heinimann $^{4,5}$
}

\begin{abstract}
Reducing Emissions from Deforestation and Forest Degradation and enhancing forest carbon stocks (REDD+) is a performance-based payment mechanism currently being debated in international and national environmental policy and planning forums. As the mechanism is based on conditionality, payments must reflect land stewards' level of compliance with carbon-efficient management practices. However, lack of clarity in land governance and carbon rights could undermine REDD+ implementation. Strategies are needed to avoid perverse incentives resulting from the commoditization of forest carbon stocks and, importantly, to identify and secure the rights of legitimate recipients of future REDD+ payments. We propose a landscapelevel approach to address potential conflicts related to carbon tenure and REDD+ benefit sharing. We explore various landtenure scenarios and their implications for carbon ownership in the context of a research site in northern Laos. Our case study shows that a combination of relevant scientific tools, knowledge, and participatory approaches can help avoid the marginalization of rural communities during the REDD+ process. The findings demonstrate that participatory land-use planning is an important step in ensuring that local communities are engaged in negotiating REDD+ schemes and that such negotiations are transparent. Local participation and agreements on land-use plans could provide a sound basis for developing efficient measurement, reporting, and verification systems for REDD+.
\end{abstract}

Key Words: carbon tenure; equity; Laos; participatory land-use planning; REDD+

\section{INTRODUCTION}

During the past 5 years, Reducing Emissions from Deforestation and Forest Degradation and enhancing forest carbon stocks (REDD+) has evolved as an important mechanism for introducing market-based initiatives as part of global attempts to reduce carbon emissions. The idea is to provide tropical forest countries with financial incentives from compliance and/or voluntary markets to preserve and enhance forest carbon stocks. In theory, this should be accompanied by biodiversity conservation and socioeconomic development in areas with low agricultural potential and limited market access (Campbell 2009). The concept of paying local stakeholders for avoiding deforestation and forest degradation and enhancing carbon stocks has found support among a wide range of actors (e.g., scientists, development practitioners, policy makers, local communities). A framework based on effectiveness, efficiency, and equity (known as the 3Es criteria) has been designed to measure the outcomes of REDD+ proposals in terms of achieving carbon sequestration at minimum cost while contributing to sustainable development (Angelsen et al. 2009). However, there are growing concerns about the feasibility of implementing at national and local levels a policy that forms part of an international initiative to address the global issue of climate change. Some scholars moderate the general enthusiasm by recalling the lessons learned from past integrated conservation and development projects, where win-win outcomes have remained elusive (Blom et al. 2010, Hirsch et al. 2010).
As REDD+ is based on conditionality, payments must reflect land stewards' level of compliance with carbon-efficient management practices. The conditionality of carbon payments is inherently related to issues of land and forest resources governance at the national and local levels. Much of the recent literature calls for governance improvements, while conceding that corruption and power struggles are likely to undermine payments for ecosystem services (PES) by fostering unsustainable activities such as deforestation (Angelsen et al. 2009, Cotula and Mayers 2009, Streck 2009). The principle of free, prior, and informed consent (FPIC) has also become prominent, and local communities' involvement in forest governance is considered a requirement for any REDD+ initiative (Anderson 2011). In particular, efforts to increase carbon sequestration will require changes in land/forest uses, which could have serious implications for local communities whose livelihoods depend on forest resources. Therefore, local stakeholders should be involved in the design of REDD+ projects and, importantly, in the clarification of current and future land uses (Agrawal et al. 2008, Kanowski et al. 2011). As it is believed that community involvement in REDD+ has the potential to improve equity in the distribution both of the benefits derived from carbon sequestration and of co-benefits (e.g., livelihood improvement, biodiversity enhancement), decentralization of forest governance could contribute to more equitable allocation of carbon rights (Charnley and Poe 2007, Chazdon 2008, Agrawal and Angelsen 2009). That is, enhanced local participation would prevent the capture of

\footnotetext{
${ }^{1}$ University of Queensland (UQ), School of Geography, Planning and Environmental Management, Brisbane, Australia, ${ }^{2}$ Institut de Recherche pour le Développement (IRD), Vientiane, Laos, ${ }^{3}$ Center for International Forestry Research (CIFOR), Bogor, Indonesia, ${ }^{4}$ Swiss National Centre of Competence in Research (NCCR) North-South, Centre for Development and Environment (CDE), ${ }^{5}$ Institute of Geography, University of Bern, Switzerland
} 
REDD+ benefits by elites from outside the community (United Nations General Assembly 2007, Sikor et al. 2010, Anderson 2011). However, translating these principles into practice has proved difficult. Of particular concern is the inadequate involvement of local communities in tenure reform and REDD+ planning (Brown et al. 2008, Cotula and Mayers 2009, Streck 2009). Many observers have been disappointed by the REDD+ readiness programs conducted by the World Bank's Forest Carbon Partnership Facility (FCPF) (Dooley et al. 2011). Similarly, critics have noted that the United Nations REDD+ (UN-REDD) Programme has failed to respect its own pledge of social commitments (Davis et al. 2009). Phelps et al. (2010) have revealed a trend toward centralization of resource control and a general neglect of indigenous rights. Others have pointed out that the lack of meaningful consultation and limited engagement with local communities are undermining the FPIC principle (Dooley et al. 2011).

The government of Laos has been involved in REDD negotiations under the United Nations Framework Convention on Climate Change (UNFCCC) since 2007, and the country became a member of the FCPF in 2008. About $41.5 \%$ of the total area of Laos is under forest cover (defined as at least $20 \%$ crown cover, over a minimum area of $0.5 \mathrm{ha}$, with a minimum mature tree height of $5 \mathrm{~m}$ ), including forest outside protected areas, which accounts for $13.9 \%$ (3.3 million ha of forest) of the country's land area (K. Ounekham, unpublished manuscript). In Laos, where $79 \%$ of the population lives in rural areas (the largest proportion in Southeast Asia), about 5.2 million people rely on forested areas for timber, food, fuel, fiber, shelter, medicines, and cultural activities (Government of Laos 2005). Forest was reportedly lost at a rate of $0.6 \%$ a year (or 134,000 ha) between 1992 and 2002 (Government of Laos 2005). Attracted by the potential of REDD+ to aid poverty reduction, forest protection, and economic development, the Department of Forestry under the Ministry of Agriculture and Forestry (MAF) has encouraged the development of REDD+ pilot activities (MAF 2011). In 2012, the newly created Ministry of Natural Resources and Environment took over the coordination of REDD+ field activities from the former national REDD+ task force.

In most such projects in Laos, participatory land-use planning (PLUP) serves as a key instrument for involving local communities in the design and implementation of REDD+ (MAF 2011). In identifying ways to reduce forest degradation and creating associated incentives, PLUP may be applied in relation not only to existing forests but also to fallows in agricultural lands where forests can be regenerated, thus making them potential carbon sinks. However, the Lao government has largely disregarded customary practices of land-use planning, which are advocated in the literature (e.g., Schlager and Ostrom 1992, Mendelsohn 1994, Wiebe and
Meinzen-Dick 1998), despite efforts targeting administrative decentralization and redistribution of land-use planning and management responsibilities among provincial and district authorities (Lestrelin et al. 2012). Several studies have reported that local communities have relatively little participation in, and adherence to, land-use planning decisions (Evrard 2004, Gesellschaft für Technische Zusammenarbeit 2004, Lestrelin et al. 2011). Thus, the empowerment and enhanced participation of local stakeholders represent important challenges for the development of REDD+ activities in Laos.

In addition, the legislation on land and forest tenure is undergoing revision because it appeared poorly suited to performance-based PES mechanisms such as REDD+ (Moore et al. 2012). Under Lao national law, the state is responsible for the centralized and uniform management of the country's land and forests (Land Law 2003: Article 3). However, individuals and organizations have full ownership of trees they have planted (National Assembly 2007: Article 4), which, in principle, constitutes a relatively solid basis for local communities and other non-governmental actors to participate in the carbon stock enhancement component of REDD+. In reality, however, the question of carbon tenure is more complex, especially in the context of avoided deforestation and degradation on existing forestland.

At the national level, the 2007 Forestry Law identifies three main categories of state forests, as follows:

- Protection forests, aimed at protecting watersheds, are subdivided into total protection zones (where all land uses are prohibited) and controlled-use zones (where limited permanent agriculture, non-commercial logging, and collection of forest products are allowed).

- Conservation forests and National Protected Areas (NPAs), aimed at preserving ecosystems and biodiversity, are subdivided into total protection zones (where all land uses are prohibited), controlled-use zones (where limited permanent agriculture, non-commercial logging, and collection of forest products are allowed), corridor zones (where collection of forest products is allowed), and buffer zones (where non-commercial logging and collection of forest products are allowed).

- Production forests, aimed at developing sustainable forestry activities, are subdivided into forest management areas (devoted to timber exploitation) and village-use zones (where permanent agriculture, non-commercial logging, and collection of forest products are allowed). Even though production forests belong to the state, they come under community management (Table 1). 
Table 1. Tenure systems for the main land-use types

\begin{tabular}{ll}
\hline \hline Tenure system & Land-use type \\
\hline Communal lands & Rotational agriculture \\
& Production forest \\
& Sacred forest \\
& Reserve land \\
Private lands & Permanent agriculture \\
& Plantations \\
State lands & Residential land \\
& Conservation forest \\
& Protection forest \\
\hline
\end{tabular}

About 14 million ha, or nearly $60 \%$ of the country's total surface area, had been designated as state production, conservation, or protection forest by 2011 (K. Ounekham, unpublished manuscript).

Outside of state forestland, a village land-use planning and land allocation system is used to define residential land, agricultural land, and the three categories of forests described above. The District Land Management Authority can issue land-use titles for land under permanent agriculture that falls into the "private lands" category (e.g., paddy, tree plantations, and annual crops, excluding swidden agriculture). Prime Ministerial Decree No. 88 on the Implementation of the Land Law (2003) also allows for collective titles to be issued for village use of production forests and rotational agricultural land (Government of Laos 2003). Nevertheless, village protection and conservation forests remain the full property of the state. If the village administration is made responsible for enforcing state regulation in these areas, no individual or collective titling is possible (Liu and Sigaty 2009). As a result, the state and its forestry administration constitute the main recipients of carbon rights on existing forestland. The process of village land-use planning thus defines local people's access to natural resources because tenure rights and land management rules are attached to each land-use type. Table 1 summarizes the tenure regimes associated with each main land use in northern Laos.

Given its history of centralized natural resource management (Lestrelin et al. 2012), Laos offers an appropriate location for exploring ways of involving local communities in REDD+ implementation described by Phelps et al. (2010). Drawing on a case study in six villages within a swidden agriculture landscape, this paper focuses on carbon tenure arrangements and their implications for REDD+ benefit sharing. We build on the insights from four complementary research approaches (PLUP, political ecology, remote sensing, and land-use change analysis) and describe the outcomes of including local stakeholders in negotiating carbon management in terms of equity and efficiency. Finally, the article discusses how action research can inform national decision makers (e.g., in terms of perceptions, expectations, and issues related to local REDD+ implementation) and influence the national-level tenure reforms that are necessary for large-scale implementation of REDD+.

\section{METHODS}

\section{Study Site}

The case study site is in Viengkham District in Luang Prabang Province, in northern Laos (Fig. 1), in a region characterized by a predominance of swidden agriculture (also called shifting cultivation or slash-and-burn) and low population density. Most villages in the district have limited access to main roads and markets, and households earn cash incomes from livestock farming and the sale of non-timber forest products (NTFPs). The six study villages form part of the village cluster of Muongmuay, which has 462 households, and borders the Nam-Et Phou Louey NPA, the second largest national park in the country.

Fig. 1. Study area: village cluster of Muongmuay in Viengkham District, Luang Prabang Province, Laos

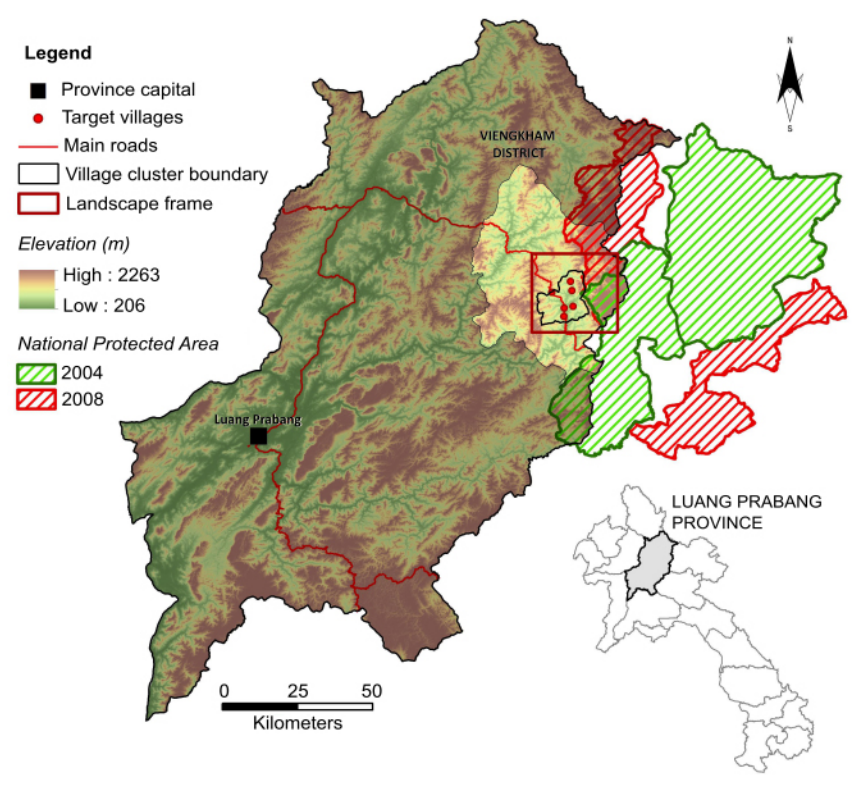

Historically, swidden agriculture with long fallow periods (over 10 years) was common in this area, and thus the densely forested mountain chain of Phou Louey, located in the eastern part of the case-study site, was under little threat of deforestation. As shown by remote-sensing data, a gradual segregation between agricultural land and forestland occurred over time (Castella et al. 2011, Hett et al. 2012), with agriculture concentrated along the only paved road and forest preserved in less accessible or protected areas (Fig. 2a). Successive land policies contributed to this segregation process between the western and eastern parts of the landscape. 
In the 1990s, the government introduced a policy of resettling villages closer to roads with the dual objective of improving people's access to state services (Evrard and Goudineau 2004) while consolidating "state control over the land" (Vandergeest 2003:48), but village resettlements intensified the pressure on agricultural land. Exacerbating the problem of the agricultural land shortage was the implementation of the "three-plot policy", associated with the land-use planning and land allocation program initiated by the Ministry of Agriculture and Forestry in the early 1990s (Castella et al. 2011). The goal was to eradicate swidden agriculture by restricting each household to three plots for rotational crops, de facto limiting the fallow period to a maximum of 3 years-and pushing the system beyond its ecological limits (Lestrelin 2010). This land policy also aimed at securing land tenure for local populations by granting households land-use certificates. However, it did not achieve the expected success in terms of improving local livelihoods, largely because of the absence of alternatives to traditional swidden agriculture (Ducourtieux et al. 2005, Lestrelin and Giordano 2007).

Fig. 2. Land-cover/use map 2009 (a) and carbon stock values 2009 (b) for the study area

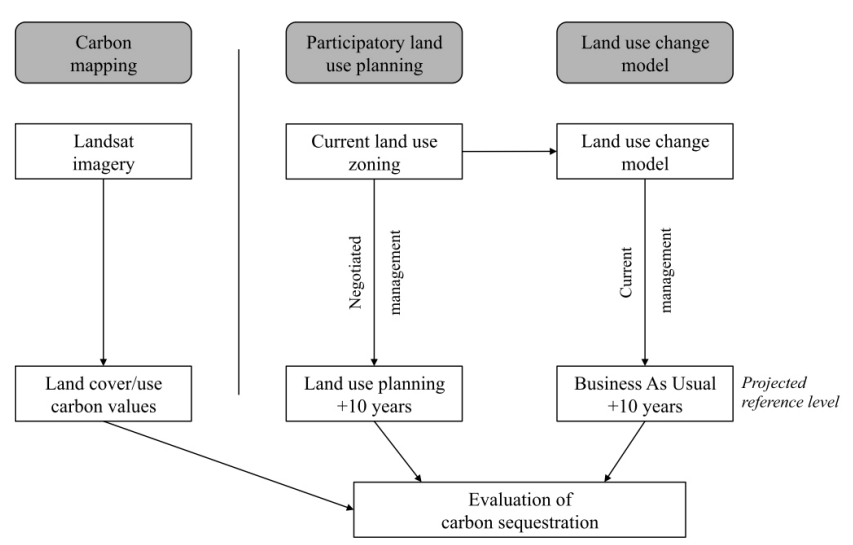

Nam-Et Phou Louey NPA was established in 1993, and its boundaries were expanded in 2008 (Fig. 1) when more villages in the vicinity were relocated along the road. This resulted in further segregation of the landscape with, on the one hand, forest regeneration in strictly protected areas and, on the other, degraded landscapes dominated by intensive agricultural activities in the most accessible areas (Fig. 2a). Although forest regeneration has obvious positive implications for biodiversity in protected areas, the reduction of the complex landscape mosaics, which retained a large share of the original forest biodiversity, was detrimental to the poor upland communities that relied on NTFPs as a safety net in periods of food shortage (Castella et al., in press).

\section{Methodological Framework}

As Ostrom and Nagendra (2006) argue, obtaining reliable and useful data on forest-people relationships is challenging and requires a combination of approaches and perspectives. In this article, we draw on insights from four complementary research approaches based on different theoretical backgrounds and disciplinary cultures. These approaches of land-use change science, livelihood analysis, participatory simulations and games, and political ecology are presented below:

- Examination of the drivers of deforestation and forest degradation through a historical perspective, i.e., analysis of historical changes in land use and livelihoods (Castella et al., in press).

- Spatial assessment of carbon stocks by Hett et al. (2011) following the detection of changes in land cover by Kongay et al. (2010).

- Application of participatory approaches to low carbon emission land-use planning, where local stakeholders are engaged in clarifying current land uses and negotiating future landscape arrangements (Bourgoin et al. 2012).

- Analysis of forest governance issues through an actornetwork perspective, that is, a political ecology approach that describes successive land use and forest policies and their drivers, implementation gaps, and impacts on landscapes and livelihoods (Lestrelin et al. 2012).

Encompassing these for research approaches, our proposed methodological framework combines carbon measurements at the landscape level with PLUP in the six study villages. A land-use change model that simulates changes in carbon management over time was used to account for carbon sequestration. The following sections describe each step of the overall approach (Fig. 3).

\section{Carbon mapping}

Kongay et al. (2010) produced land cover/use maps for Viengkham District through visual interpretation of a chronological series of Landsat satellite images combined with ground truth surveys conducted in 2009. They identify seven classes of land cover/use: upland crop, recent fallow, shrub (which includes swidden agriculture systems), dense forest, open forest, paddy rice, and other land cover. In another approach, Hett et al. (2011) describe in detail how they derived carbon values from the Intergovernmental Panel on Climate Change (IPCC) (2007) biomass data and associated other landuse/cover categories with those values. We combined the two methodologies by simplifying Kongay et al.'s (2010) landuse/cover classes using the terms in Hett et al. (2011) and adopted the following four categories: agricultural land (upland crop, paddy rice), young regrowth (recent fallow), degraded forest (shrub and open forest), and natural forest (dense forest). To carry out the carbon mapping of the study 
area, we applied the carbon values in $\mathrm{tC} / \mathrm{ha}$ estimated by Hett et al. (2011) to each of these four classes.

Fig. 3. Methodological framework combining carbon mapping and participatory approaches to evaluate carbon sequestration through different management strategies

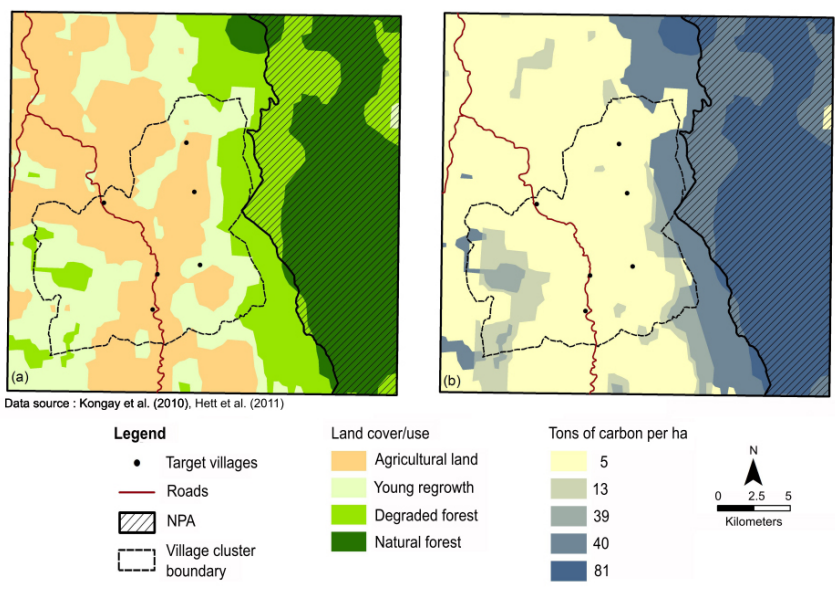

\section{Participatory land-use planning}

We conducted action research in each of the six study villages of the village cluster of Muongmuay in 2009-2010 to assess the spatial distribution of current (2010) and planned (2020) land uses in the study site. This project, whose aim was to enhance communities' participation in land-use planning, involved a range of actors, from international and national scientists to local authorities and village communities. During the initial learning phase, local villagers involved in the village land management committee designed a land-use plan for a fictional village. This involved a role-playing game named "PLUP Fiction" that was used in combination with participatory 3D modeling to clarify the links between landuse planning decisions and their consequences for livelihoods (Bourgoin and Castella 2011, Bourgoin et al. 2012). Participants manipulated simple figures corresponding to socioeconomic and environmental returns per hectare from each type of land use in their village. This participatory approach to evaluating land-use scenarios facilitated the comprehension of planning impacts on livelihood and environmental indicators, and motivated further negotiations among the villagers regarding land-use planning. The game gave the participants the opportunity (1) to define a collective land-use strategy for the virtual landscape displayed on the game board and (2) to become aware of the relationships among landscape composition, land rights, and access to natural resources. The game was also used to introduce the concepts of carbon payments and REDD+, and local stakeholders could then modify their plans based on this new parameter (namely, carbon payments).
After this learning phase, the participants considered the landuse zoning and planning of the actual village. By employing a socioeconomic and environmental assessment tool based on a participatory geographic information system (GIS), members of the village land management committee along with government representatives could explore alternative landscape-change scenarios and assess their implications in terms of resource management strategies (Bourgoin 2012). The process is iterative; after the model outputs have been communicated to the actors, they are free to modify the landuse plans and negotiate new arrangements until they reach an agreement on consensual management rules for the next 10 years that will then be endorsed by the district administration. For both current zoning and future land-use planning, local stakeholders clarified the tenure system by identifying communal, private, and state lands (Table 1).

\section{Land-use change model}

Land-use plans incorporate local demand for agricultural innovations and/or changes in land uses that will be supported by government extension services and/or development projects (Bourgoin et al. 2012). To determine the value of negotiated management (through PLUP) in terms of carbon sequestration, we built a business-as-usual (BAU) scenario using a land-use change model that corresponds to current management practices (Fig. 4). As the participatory land-use plan is a 10-year projection of the negotiated future land use, we then applied a land-use change model based on a deterministic transition matrix to estimate land-cover changes after 10 years of the BAU land management practices. The results (Table 2) are based on expert knowledge, and the numbers in the matrix reflect changes in land-use/cover classes over the 10-year forecast period. We then compared the patterns of carbon sequestration generated under each landuse plan (Fig. 4).

\section{RESULTS}

By applying the methodology described above, we were able to capture the spatial distribution of carbon stocks and forecast changes at the landscape level. In this way, we elicited useful information about the expected volume of carbon credits that could be generated under each tenure system. In the present research, we visualized the distribution of carbon stocks in the landscape in a GIS by computing the carbon values for each land cover/use category. Figure 2 presents a land cover/use map and carbon stock densities for the study area, with the total estimated value of 2,146,113 tons of carbon $(\mathrm{tC})$ for the study window. As seen, when the existing administrative geometry is superimposed on the carbon density layer, the NPA (in the eastern part of the landscape) harbors $70 \%$ of the total amount of carbon in the study window, even though it covers only $30 \%$ of the area. However, at the national level, a greater proportion of the carbon stock in Laos is outside NPAs: NPAs have higher carbon density but cover a relatively small area of the national territory (Hett et al. 2011). This 
Table 2. Transition matrix for the land-cover/use change model (the numbers correspond to land-cover/use classes displayed in the first column)

\begin{tabular}{|c|c|c|c|c|c|c|c|}
\hline \multirow[b]{2}{*}{ Land cover/use (classes) } & \multicolumn{7}{|c|}{ Evolution of land cover under management (10 years) } \\
\hline & $\begin{array}{c}\text { Forest } \\
\text { conservation }\end{array}$ & $\begin{array}{c}\text { Forest } \\
\text { protection }\end{array}$ & $\begin{array}{c}\text { Forest } \\
\text { production }\end{array}$ & $\begin{array}{l}\text { Annual } \\
\text { crops }\end{array}$ & Plantations & $\begin{array}{c}\text { Reserve } \\
\text { land }\end{array}$ & $\begin{array}{c}\text { Built-up and } \\
\text { permanent areas }\end{array}$ \\
\hline Swidden agriculture $(1)$ & 2 & 2 & 2 & 1 & 2 & 2 & 5 \\
\hline Shrub / tree fallow (2) & 3 & 3 & 2 & 1 & 2 & 2 & 5 \\
\hline Open forest (3) & 4 & 4 & 3 & 1 & 2 & 3 & 5 \\
\hline Dense forest (4) & 4 & 4 & 3 & 1 & 2 & 3 & 5 \\
\hline Built-up areas (5) & 5 & 5 & 5 & 5 & 5 & 5 & 5 \\
\hline
\end{tabular}

observation lends support to the proposal to include more agriculture/forest mosaics because of their potential for carbon sequestration. Moreover, as most villages are located outside the NPAs, poor, forest-dependent communities may not benefit from carbon payments. To assess how including local stakeholders in negotiations of carbon management would affect the efficiency of REDD+ (i.e., carbon sequestration), we focused on the complex agriculture/forest mosaics where most forest degradation occurs (Castella et al. in press, Moore et al. 2012).

Fig. 4. Participatory land-use plan and cumulated carbon sequestration for each land-use polygon over a 10-year period for the village cluster of Muongmuay
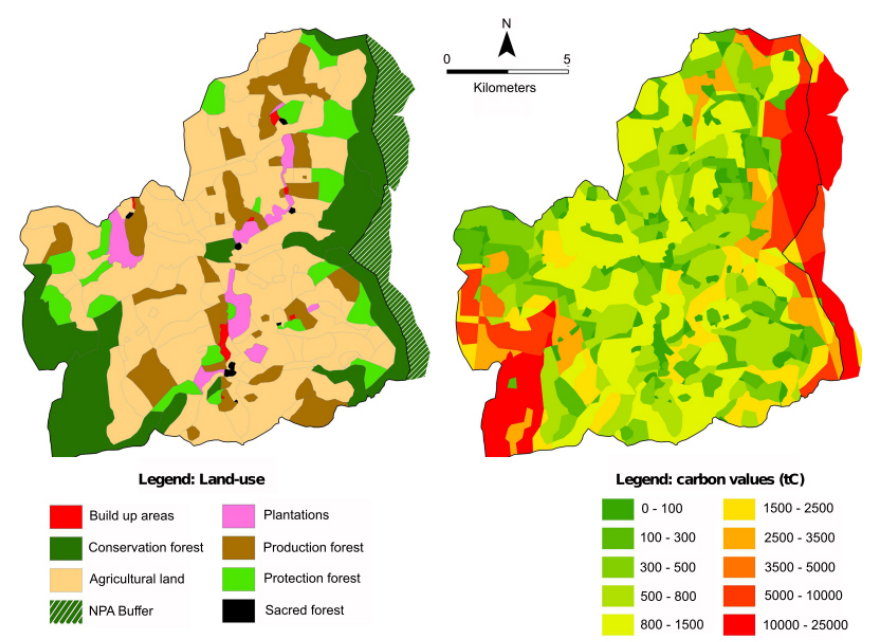

The land-use plan negotiated by the villagers and endorsed by the local government was overlaid on the carbon map estimated from the current land cover. Within the villagecluster boundaries, the estimated carbon stock is 240,076 tons (Fig. 2b). We chose this village-cluster carbon stock as the reference level to evaluate the amount of carbon sequestered over 10 years, based on the plans made during PLUP. The transition matrix (Table 2) was used to estimate the future land cover based on the management strategy established through PLUP. A comparison of the distribution of the current and projected land-use/cover stages reveals an increase of $44 \%$ in carbon storage after 10 years of implementation of the landuse plan negotiated through PLUP. Furthermore, a comparison of the amounts of carbon stored with the PLUP land-use plan and the BAU projected reference level reveals that an additional 20,870 tons is stored under the PLUP-derived plan (Table 3). We attribute this difference to the decrease in swidden areas and the increase in forested areas under the PLUP-derived plan (Table 2). As presented in Table 1, land zoning de facto associates land tenure rights with land-use types. When overlaying the tenure rights on the PLUP map in a GIS (Fig. 5a), we observe that, even within the village territories, $90 \%$ of the carbon is found in state forests and the remaining $10 \%$ is in communal or private forests.

Fig. 5. Representation of the tenure systems generated by different management strategies for the village cluster of Muongmuay

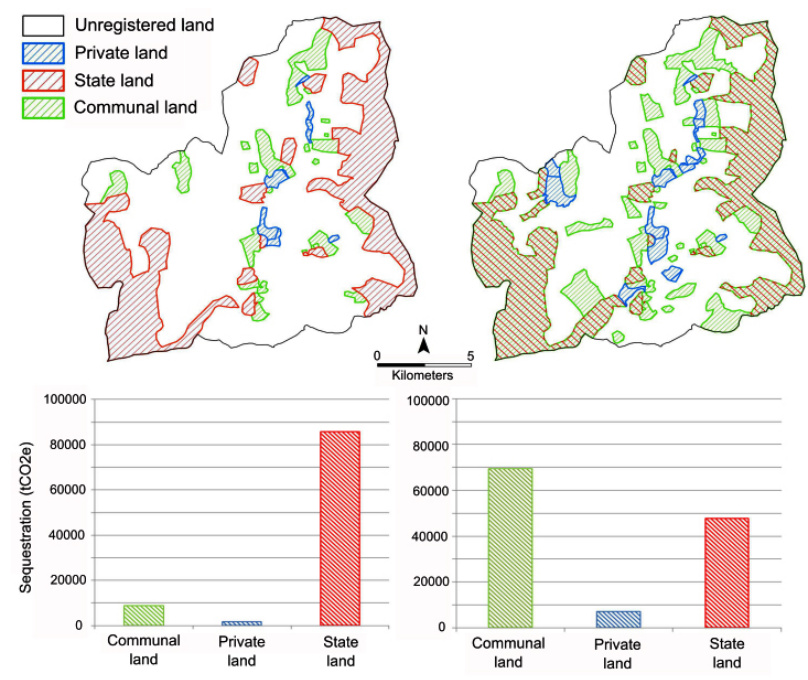


Table 3. Carbon sequestration after 10 years under different management strategies (BAU, PLUP)

\begin{tabular}{lrrrr}
\hline \hline Tenure system & Communal lands & Private lands & \multicolumn{2}{c}{ State lands } \\
\hline Carbon sequestration under BAU & $-4 \%(-3372.8 \mathrm{tC})$ & $2 \%(1686.4 \mathrm{tC})$ & $102 \%(86006.4 \mathrm{tC})$ & $84,320 \mathrm{tC}$ \\
Carbon sequestration under PLUP & $3 \%(3155.7 \mathrm{tC})$ & $7 \%(7363.3 \mathrm{tC})$ & $91 \%(95722.9 \mathrm{tC})$ & $105,190 \mathrm{tC}$ \\
\hline
\end{tabular}

\section{DISCUSSION}

In the current legal and regulatory context in Laos, government agencies mainly hold forest carbon rights, and so are expected to be the main beneficiaries of REDD+ schemes. Nongovernmental organizations and private enterprises may also become important recipients of REDD+ payments through sustainable forestry initiatives and plantation concessions. The situation is more ambiguous for local communities. Currently, they can retain carbon rights over planted forestland and can claim collective land rights over village production forests. However, they are not eligible for land (and a fortiori carbon) rights in the carbon-rich areas (i.e., state and village protection and conservation forests) that will generate the greatest benefits from REDD+ payments. Who will benefit from carbon payments will depend on which REDD+ implementation strategies are adopted at the national level.

Two main scenarios emerge as possibilities. Under a scenario known as "state capture," REDD+ projects would concentrate on densely forested areas, i.e., the NPA in the eastern side of our study landscape. This scenario considers the criticisms that have been leveled at people-centered approaches for leading to weak, decentralized governance and cumbersome institutional reforms. According to the Wildlife Conservation Society, law enforcement would be the most efficient mechanism for avoiding deforestation and forest degradation in the state forest because of the presence of infrastructure and villages within and bordering the park (Moore et al. 2011). State-piloted REDD+ projects would deliver carbon credits to the NPA, and this additional revenue could be used to pay rangers to patrol the forest and monitor park dwellers' activities.

Under an alternative scenario known as "state redistribution to communities", local communities would become partners in natural resource management inside and around the park. It has been noted that giving local people social control over park boundaries and control of illegal activities (i.e., logging, poaching, and forest encroachment by swiddeners) creates a cost-effective system (Agrawal and Chhatre 2009). Sharing carbon credits with villages inside and around the park is seen as a form of compensation for the loss of access to forest resources for local communities that traditionally depend on forests for their livelihood (e.g., NTFP collection, hunting). Borner et al. (2011) call for a combination of law enforcement "sticks" and payment "carrots" as a way of increasing equity. As carbon credits are essentially generated from state forest, benefit-sharing arrangements would be at the discretion of the forest landowner, i.e., the NPA authorities-which could jeopardize the equity principle.

As noted by Phelps et al. (2010), REDD+ may actually reverse decentralization trends by strengthening the state in its new role as carbon accountant. However, if efficiency and equity are to be maximized, the role of local communities must go beyond data collection for forest monitoring. To ensure fair distribution of co-benefits and to provide the incentives necessary to ensure local communities stay involved beyond the planning phases, participatory approaches need to be complemented by national tenure reforms (Larson 2011, Palmer 2011). Importantly, the success of REDD+ depends on titles being granted for existing forestland and/or the establishment of forest management contracts. Village Land and Forest Management Agreements established during PLUP and certified by the district administration could serve as binding contracts and prevent land grabs by external investors motivated by the commoditization of the forests' carbon (Palmer-Fry 2011). Such agreements, however, have important limits in terms of tenure security vis-à-vis land concessions and state development projects. Ultimately, if local communities are not granted strong forest tenure and carbon rights, REDD+ could actually further marginalize local stakeholders, who are already largely excluded from management of carbon-rich areas because of village resettlements and land-use regulations.

In the experiment described in this paper, engaging villagers in planning for REDD+ through PLUP created a strong sense of ownership in the community in terms of both process and outcome. In the successive iterations of the participatory planning process, villagers agreed to increase the size of production forests; in other words, they agreed to allow the regeneration of certain fallow areas where they could continue to collect NTFPs and wood for their own consumption. Thus, the negotiated approach enabled more carbon storage than a BAU model and secured, with relatively little investment, the consent of local communities (Anderson 2011). Essentially, PLUP represents a way of empowering local communities and involving them in decision making (Lyster 2011). This propoor approach could also facilitate community-based monitoring and ease discussions around REDD+ implementation issues (Danielsen et al. 2011). Lessons from this example of local implementation and on-the-ground empirical knowledge could feed policy formulation processes 
and foster land-tenure reforms that would enable a more effective and more equitable REDD+ mechanism (Karsenty and Ongolo 2012, Palmer 2011). For instance, although the participatory process seems crucial in terms of enhanced legitimacy, efficiency, and effectiveness of REDD+ implementation, it remains doubtful whether it will benefit equity, the last parameter of the "3Es equation" (Angelsen et al. 2009) in the absence of reforms for land carbon tenure.

The focus for REDD+ mechanisms seems to be on maximizing the effectiveness of carbon storage, but overlooking equity could prove detrimental for the feasibility of REDD+ projects by alienating local communities and increasing potential land conflicts and deforestation (Angelsen et al. 2009). As noted by Cotula and Mayers (2009), experiments in local tenure and social justice must take precedence to engage with national decision makers and highlight potential weaknesses in current land and forestry laws if the country wishes to engage in REDD+. The current legal system should be harmonized with REDD+ principles. It should also go beyond the illusion that markets and economic incentives alone will safeguard forest health (Borner et al. 2010). Policy innovations at the national level should acknowledge the need to share the costs and benefits of REDD+ between the state and individuals (Palmer 2011). A co-management agreement established at the national level could be translated into practice by the shared management of forested lands within village boundaries (Carlsson and Berkes 2005). Through this partnership, social control could efficiently be mixed with current command-andcontrol approaches (Borner et al. 2010). Balancing of powers could prevent potential drifts toward unsustainable measures by both sides.

The tenure map in Fig. 5b shows that, under co-management, carbon sequestration and the potential co-benefits attached to it would create more balance between communal and state land. Securing tenure rights of local populations over communal lands could incentivize land management changes toward less intensive swidden systems and carbon sequestration in complex landscape mosaics. This would be an important step toward the demystification of swidden agriculture and rehabilitation of agroforestry systems in political circles (van Noordwijk et al. 2008). As emphasized by Hett et al. (2012:609), a REDD+ scheme could be used to revert to long crop-fallow periods, "raising the carbon stocks at the landscape level." Swidden agriculture remains excluded from current land registration processes, and therefore, from REDD+ schemes. A clarification of tenure rules combined with an innovative method of measurement, reporting, and verification specific to swidden landscapes are necessary to allow local stakeholders to benefit from carbon sequestration in the complex agriculture/forest mosaics that they have been managing for many generations (Fox et al. 2011, Hett et al. 2012).
In a context of centralized forest governance, the approach and tools described in this article could support enhanced participation of local communities in decision making on land use and forest carbon stock management. The rationale here was to propose a landscape planning perspective that defines management strategies and rules at the village level before land is actually allocated for a certain use. The experiment in Viengkham District exemplifies the methodological improvements required to bridge PLUP and carbon assessments from satellite imagery. At this stage of the research, more emphasis was put on the level of community engagement than on the accuracy of the land-use/carbon models. In this respect, complex issues related to how REDD+ will actually function (e.g., leakage issues) have been deliberately overlooked. In addition, the land-use change model is simplified and constrained by the deterministic nature of the transition matrix. Linear changes between land-use/ cover categories bypass land conversion decisions that may occur in a BAU scenario over a 10-year period. More sophisticated models combined with carbon monitoring in reference areas may provide more realistic values for carbon sequestration under BAU. This issue forms part of the iREDD+ research project (http://i-redd.eu/). Nevertheless, the method used here demonstrates the importance of secured communal land-tenure rights if the REDD+ scheme is to benefit local stakeholders in swidden landscapes.

\section{CONCLUSION}

Our research showed that participatory approaches combined with spatial analysis of land use and carbon stocks at the landscape level can make an important contribution toward enhancing efficiency in carbon sequestration by empowering local communities through relevant scientific knowledge and tools to negotiate REDD+ arrangements. By facilitating local understanding of socioenvironmental issues and allowing stakeholders to reflect on their future, this innovative approach may provide a valuable insight on the local implementation of REDD+ mechanisms. It could also contribute to reshaping power relationships, which have long undermined land-use planning implementation in Laos. Importantly, the PLUPbased approach to REDD+ allows for broader and bettershared access to the knowledge that is required for negotiations on carbon sequestration at the local level.

We offer insight for those who take participation as an end in itself. Although clear tenure rights and community participation are critical to the success and sustainability of REDD+, they represent only one step toward an effective and equitable REDD+. Tenure reforms made at the national level will ultimately be necessary for addressing local people's individual and collective rights. 
Responses to this article can be read online at: http://www.ecologyandsociety.org/issues/responses. $\mathrm{php} / 5362$

\section{Acknowledgments:}

The participatory land-use planning approach presented in this paper was applied within the framework of two research programs: the Landscape Mosaics Program, led by the National Agriculture and Forestry Research Institute (NAFRI, Laos) and the Center for International Forestry Research (CIFOR, Indonesia) and funded by the Swiss Agency for Development and Cooperation (SDC); and the Comprehensive Analysis of the Trajectories of Changes (Catch-Up) Program supported by CIFOR and the Institut de Recherche pour le Développement (IRD, France). This research is also part of the project entitled Impacts of Reducing Emissions from Deforestation and Forest Degradation and Enhancing Carbon Stocks (I-REDD+). I-REDD+ is funded by the European Community's Seventh Framework Research Programme. More information can be found at http://www.i-redd.eu.

\section{LITERATURE CITED}

Agrawal, A., and A. Angelsen. 2009. Using community forest management to achieve REDD+ goals. Pages 201-211 in A. Angelsen, M. Brockhaus, M. Kanninen, E. Sills, W. Sunderlin, and S. Wertz-Kanounnikoff, editors. Realising REDD+: national strategy and policy options. CIFOR, Bogor, Indonesia.

Agrawal, A., A. Chhatre, and R. Hardin. 2008. Changing governance of the world's forests. Science 320:1460-1462.

Agrawal, A., and A. Chhatre. 2009. Trade-offs and synergies between carbon storage and livelihood benefits from forest commons. Proceedings of the National Academy of Sciences of the United States of America 106:17667-17670. http://dx. doi.org/10.1073/pnas.0904862106

Anderson, P., editor. 2011. Free, prior, and informed consent in REDD+: principles and approaches for policy and project development. RECOFTC and GIZ, Bangkok, Thailand.

Angelsen, A., M. Brockhaus, M. Kanninen, E. Sills, W. Sunderlin, and S. Wertz-Kanounnikoff, editors. 2009. Realising REDD+: national strategy and policy options. CIFOR, Bogor, Indonesia.

Blom, B., T. Sunderland, and D. Murdiyarso. 2010. Getting REDD+ to work locally: lessons learned from integrated conservation and development projects. Environmental Science and Policy 13:164-172.
Borner, J., S. Wunder, S. Wertz-Kanounnikoff, G. Hyman, and N. Nascimento. 2011. REDD sticks and carrots in the Brazilian Amazon: assessing costs and livelihood implementations. CCAFS Working Paper No. 8. CGIAR Research on Climate Change Agriculture and Food Security, Copenhagen, Denmark.

Borner, J., S. Wunder, S. Wertz-Kanounnikoff, M. Rugnitz Tito, L. Pereira, and N. Nascimento. 2010. Direct conservation payments in the Brazilian Amazon: scope and equity implications. Ecological Economics 69:1272-1282.

Bourgoin, J. 2012. Sharpening the understanding of socioecological landscapes in participatory land use planning: a case study in Lao PDR. Applied Geography 34:99-110.

Bourgoin, J., and J.-C. Castella. 2011. "PLUP FICTION": landscape simulation for participatory land use planning in northern Lao PDR. Mountain Research and Development 31:78-88. http://dx.doi.org/10.1659/MRD-JOURNAL-D-10-00129.1

Bourgoin, J., J.-C. Castella, D. Pullar, G. Lestrelin, and B. Bouahom. 2012. Toward a land zoning negotiation support platform: "tips and tricks" for participatory land use planning in Laos. Landscape and Urban Planning 104:270-278.

Brown, D., S. Seymour, and L. Peskett. 2008. How do we achieve REDD+ co-benefits and avoid doing harm? Pages 107-118 in A. Angelsen, editor. Moving ahead with REDD: issues, options, and implications. CIFOR, Bogor, Indonesia.

Campbell, A. 2009. Beyond Copenhagen: REDD-plus, agriculture, adaptation strategies and poverty. Global Environmental Change 19:397-399.

Carlsson, L., and F. Berkes. 2005. Co-management: concepts and methodological implications. Journal of Environmental Management 75:65-76.

Castella, J.-C., M. Thephavanh, V. Vongkhamsao, K. Mouaxeng-Cha, S. Phonphakdy, Y. R. Fitriana, K. Kongay, S. Phaipasith, J. Ferrand, V. Manivanh, and J.-L. Pfund. 2011. Evolving relations between agriculture and forests in Viengkham District, Luang Prabang Province. Lao Journal of Agriculture and Forestry 23:62-90.

Castella, J. C., G. Lestrelin, C. Hett, J. Bourgoin, Y. R. Fitriana, A. Heinimann, and J.-L. Pfund. 2013. Effects of landscape segregation on livelihood vulnerability: moving from extensive shifting cultivation to rotational agriculture and natural forests in northern Laos. Human Ecology, in press.

Charnley, S., and M. Poe. 2007. Community forestry in theory and practice: where are we now? Annual Review of Anthropology 32:301-336. 
Chazdon, R. L. 2008. Beyond deforestation: restoring forests and ecosystem services on degraded lands. Science 320:14581460 .

Cotula, L., and J. Mayers. 2009. Tenure in REDD+: start-point or afterthought? Natural Resources Issues No. 15. Institute for Environment and Development, London, UK.

Danielsen, F., M. Skutsch, N. D. Burgess, P. M. Jensen, H. Andrianandrasana, B. Karky, R. Lewis, J. C. Lovett, J. Massao, Y. Ngaga, P. Phartiyal, M. K. Poulsen, S. P. Singh, S. Solis, M. Sorensen, A. Tewari, R. Young, and E. Zahadu. 2011. At the heart of REDD+: a role for local people in monitoring forests? Conservation Letters 4:158-167.

Davis, C., F. Daviet, S. Nakhooda, and A. Thuault. 2009. A review of 25 readiness plan idea notes from the World Bank Forest Carbon Partnership Facility. WRI Working Paper. World Resources Institute, Washington, D.C., USA.

Dooley, K., T. Griffiths, F. Martone, and S. Ozinga. 2011. Smoke and mirrors: a critical assessment of the Forest Carbon Partnership Facility. FERN and Forest Peoples Programme, Brussels, Belgium.

Ducourtieux, O., J.-R. Laffort, and S. Sacklokham. 2005. Land policy and farming practices in Laos. Development and Change 36:499-526.

Evrard, O. 2004. La mise en oeuvre de la réforme foncière au Laos: impacts sociaux et effets sur les conditions de cie en milieu rural. Food and Agriculture Organization of the United Nations, Rome, Italy.

Evrard, O., and Y. Goudineau. 2004. Planned resettlement, unexpected migrations and cultural trauma in Laos. Development and Change 35:937-962.

Fox, J., J.-C. Castella, and A. D. Ziegler. 2011. Swidden, rubber and carbon: can REDD+ work for people and the environment in mountain mainland Southeast Asia? CCAFS Working Paper No. 9. CGIAR Research Program on Climate Change, Agriculture and Food Security (CCAFS), Copenhagen, Denmark.

Government of Laos. 2003. National growth and poverty eradication strategy. Government of the Lao People's Democratic Republic, Vientiane, Lao PDR.

Government of Laos. 2005. Forestry strategy to the year 2020. Government of the Lao People's Democratic Republic, Vientiane, Lao PDR.

Gesellschaft für Technische Zusammenarbeit. 2004. Study on land allocation to individual households in rural areas of Lao $P D R$. Deutsche Gesellschaft für Technische Zusammenarbeit, Vientiane, Lao PDR.
Hett, C., A. Heinimann, and P. Messerli. 2011. Spatial assessment of carbon stocks of living vegetation at the national level in Lao PDR. Danish Journal of Geography 111:1-6.

Hett, C., J.-C. Castella, A. Heinimann, P. Messerli, and J.-L. Pfund. 2012. A landscape mosaics approach for characterizing swidden systems from a REDD+ perspective. Applied Geography 32:608-618.

Hirsch, P., W. M. Adams, J. P. Brosius, A. Zia, N. Bariola, and J. L. Dammert. 2010. Acknowledging conservation tradeoffs and embracing complexity. Conservation Biology 25:259-264.

Intergovernmental Panel on Climate Change (IPCC). 2007. Climate change 2007: synthesis report. Intergovernmental Panel on Climate Change, Geneva, Switzerland.

Kanowski, P. J., C. L. McDermott, and B. W. Cashore. 2011. Implementing REDD+: lessons from analysis of forest governance. Environmental Science and Policy 14:111-117.

Karsenty, A., and S. Ongolo. 2012. Can "fragile states" decide to reduce their deforestation? The inappropriate use of the theory of incentives with respect to the REDD mechanism. Forest Policy and Economics 18:38-45.

Kongay K., S. Phaipasith, J. Ferrand, J.-C. Castella. 2010. Land-use/land cover change analysis in Viengkham district, Luang Prabang Province, Lao PDR. National Agriculture and Forest Research Institute of Lao PDR (NAFRI) and the Center for International Forestry Research (CIFOR), Vientiane, Lao PDR.

Land Law. 2003. Land Law No. 04/NA, dated 21 October 2003. Translation endorsed by the Law Committee of the National Assembly of the Lao PDR, Vientiane, Lao PDR.

Larson, A. 2011. Forest tenure reform in the age of climate change: lessons for REDD+. Global Environmental Change 21:540-549.

Lestrelin, G. 2010. Land degradation in the Lao PDR: discourses and policy. Land Use Policy 27:424-439.

Lestrelin, G., J. Bourgoin, B. Bouahom, and J.-C. Castella. 2011. Measuring participation: case studies on village landuse planning in northern Lao PDR. Applied Geography 31:950-958.

Lestrelin, G., J.-C. Castella, and J. Bourgoin. 2012. Territorializing sustainable development: the politics of landuse planning in the Laos. Journal of Contemporary Asia 42(4).

Lestrelin, G., and M. Giordano. 2007. Upland development policy, livelihood change and land degradation: interactions from a Laotian village. Land Degradation and Development 18:55-76. 
Liu, M., and T. Sigaty. 2009. Legal analysis of communal land and communal title in the Lao PDR. Rights LINK Project, Vientiane, Lao PDR.

Lyster, R. 2011. REDD+, transparency, participation and resource rights: the role of law. Environmental Science and Policy 14:118-126.

Mendelsohn, R. 1994. Property rights and tropical deforestation. Oxford Economic Papers 46:750-756.

Ministry of Agriculture and Forestry (MAF). 2011. Annual review of REDD+ activities in Lao PDR. Ministry of Agriculture and Forestry, Department of Forestry, Vientiane, Lao PDR.

Moore, C., T. Hansel, and A. Johnson. 2012. REDD+ in Lao PDR: is it also a "plus" for forest-dependent communities? A case study from the Nam Et Phou Louey National Protected Area, Lao PDR. Pages 83-92 in L. Naughton-Treves and C. Day, editors. Lessons about land tenure, forest governance and REDD+. Land Tenure Center, University of WisconsinMadison, Madison, Wisconsin, USA.

Moore, C., J. Ferrand, and X. Khiewvongphachan. 2011. Assessing the feasibility of REDD project in the Nam Et Phou Louey National Protected Area, Laos, to access the voluntary carbon market. Planet Action Feedback Report, Wildlife Conservation Society, Vientiane, Lao PDR. [online] URL: http://www.planet-action.org/automne_modules_files/polyProjects/ public/r9474_93_planet_action_feedback_report.pdf

National Assembly. 2007. Forestry Law. National Assembly of the Lao People's Democratic Republic, Vientiane, Lao PDR.

Ostrom, E. and H. Nagendra. 2006. Insights on linking forests, trees, and people from the air, on the ground, and in the laboratory. Proceedings of the National Academy of Science 103:19224-19231. http://dx.doi.org/10.1073/pnas.0607962103

Palmer, C. 2011. Property rights and liability for deforestation under REDD+: implications for "permanence" in policy design. Ecological Economics 70:571-576.

Palmer-Fry, B. 2011. Community forest monitoring in REDD+: the "M" in MRV? Environmental Science and Policy 14:181-187.

Phelps, J., E. Webb, and A. Agrawal. 2010. Does REDD+ threaten to recentralize forest governance. Science 328:312313.

Schlager, E., and E. Ostrom. 1992. Property-rights regimes and natural resources: a conceptual analysis. Land Economics 68:249-262.
Sikor, T., J. Stahl, T. Enters, J. C. Ribot, N. Singh, W. Sunderlin, and L. Wollenberg. 2010. REDD-plus, forest people's rights and nested climate governance. Global Environmental Change 20:423-425.

Streck, C. 2009. Rights and REDD+: legal and regulatory considerations. Pages 151-162 in A. Angelsen, M. Brockhaus, M. Kanninen, E. Sills, W. Sunderlin, and S. WertzKanounnikoff, editors. Realising REDD+: national strategy and policy options. CIFOR, Bogor, Indonesia.

United Nations General Assembly. 2007. United Nations Declaration on the Rights of Indigenous Peoples: resolution/ adopted by the General Assembly. Available online at http:// www.un.org/esa/socdev/unpfii/documents/DRIPS en.pdf

van Noordwijk, M., E. Mulyoutami, N. Sakuntaladewi, and F. Agus. 2008. Swiddens in transition: shifted perceptions on shifting cultivators in Indonesia. World Agroforestry Centre, Bogor, Indonesia.

Vandergeest, P. 2003. Land to some tillers: developmentinduced displacement in Laos. International Social Science Journal 55:47-56.

Wiebe, K. D., and R. Meinzen-Dick. 1998. Property rights as policy tools for sustainable development. Land Use Policy 15:203-215. 